\title{
THE CONCEPT OF PESTICIDE-FREE PEST CONTROL IN THE CRIMEAN FORESTS
}

\author{
ANATOLIY IVASHOV, ANDRIY SIMCHUK
}

\begin{abstract}
Oak leafroller, gypsy and winter moths contribute to a pathological situation in the Crimean forests exposed to strong recreational activities, which add to the weakening of the forest ecosystems. In this respect we develop a concept of pesticide-free forest protection that presupposes an optimal balance between natural self-regulation opportunities and management, taking into account the long-term effects. The practical steps include preventive and current biological pest control, different in primary, secondary and tertiary niduses of pest outbreaks in the Crimean forests. All pest-control measures should be elaborated as a successive chain of steps joining in a common ecologically and economically sound system. Preventive and current biocontrol actions become easy and soft with increase in the forest's ecosystem complexity and restoration of natural self-regulation.
\end{abstract}

Keywords: Pests, Forest management, Bio-control.

\section{INTRODUCTION}

Forest simulation usually begins from elaboration of conceptual approaches. This preliminary step is important because conceptual mistakes could not be corrected with only further mathematical manipulations $[1,2]$. As proceeds from the experience, only initial correct postulates allow constructing a forest simulation to generate policy contingent distributions of outcomes [3].

Forest pests as a rule show relatively rare-repeated outbreaks. From one hand, strong repeated defoliation may influence tree viability. From another hand, artificial interference with natural selfregulation could break sustainable community. In this respect pest control activities are often groundless and a decision on them should follow preliminary prognostic simulation predicting their economic effects [4].

Alternative methods of forest management, including these aspects, were shown on the instance of forest protective activity against western spruce budworm in Canada [3]. Successful decision-creating system, elaborated from the computer database on 145 moths from Europe, has already been created in Netherlands. It considers population parameters of pests, their entomophagans and host plants. Managers have successfully used this system for optimisation of the pest control in national reserves, natural and urban parks [5]. 
Thus, acceptable strategy in forest management should take into account the long-term effects of protective manipulations [1], elaborating the criteria for the forest ecosystem sustainable development [6].

Crimean forests are exposed to a strong anthropogenic pressure due to intensive recreational activity in nearest areas. In this respect pesticide-free control of forest pests in Crimea is a necessary goal.

\section{DISCUSSION}

\subsection{SHORT DESCRIPTION OF THE CRIMEAN FORESTS}

The forests of the Crimean peninsula grow in the very south of the Ukraine. Now their area exceeds 300,000 ha. They stretch in a broad swathe from Sevastopol northeast to Planerskoye and Pheodosia, and from Zuya in the north southward to Alushta (Figure 1). They are regularly dissected by agricultural areas throughout their margins along the Black Sea coast. "Jaylas," or mountain meadows substitute them on the mountain tops.

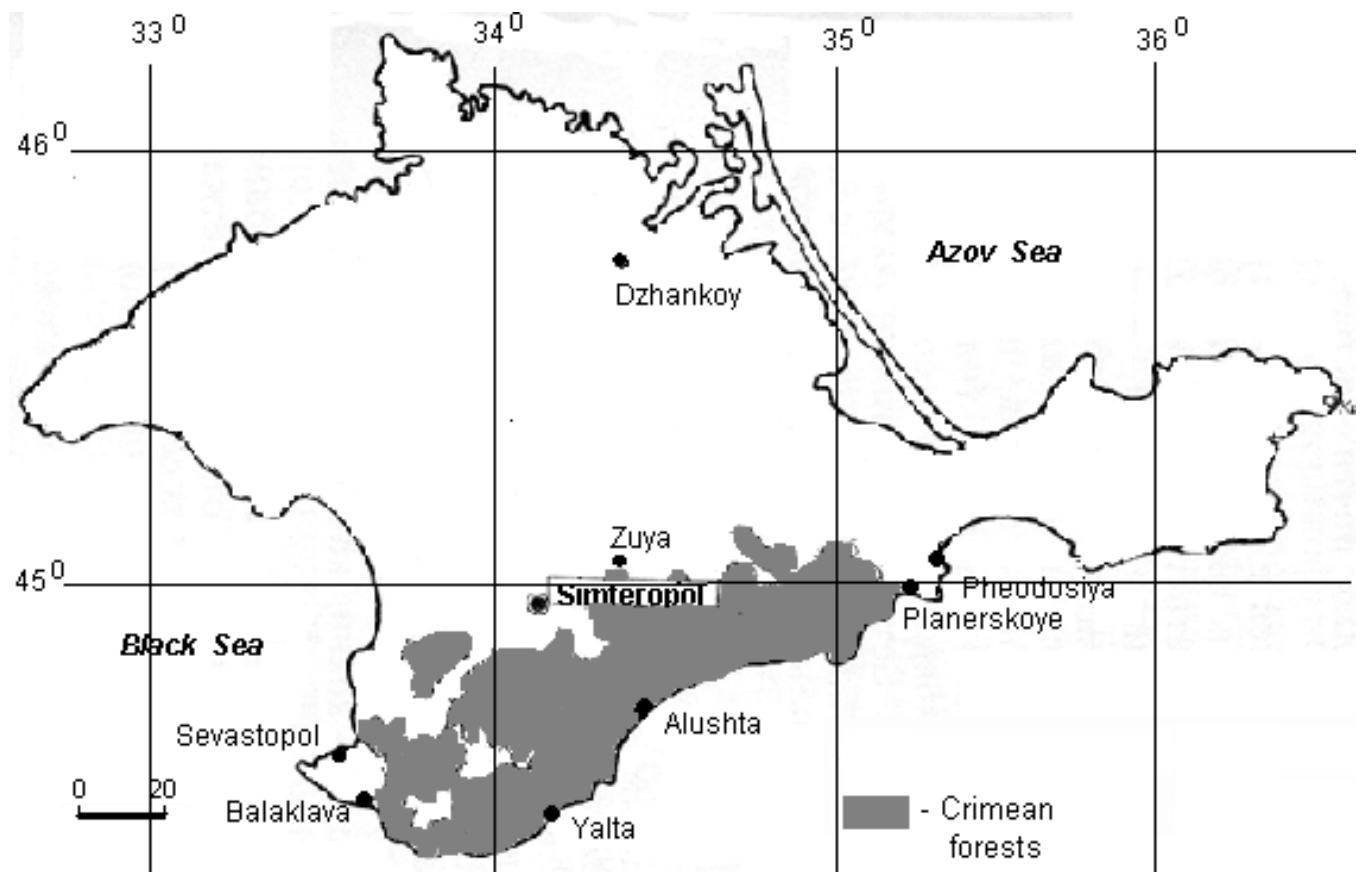

Fig. 1. Map of the Crimean forests.

Crimean forests are mainly represented by young-wood areas and forest patches, what produces a favourable environment for pest outbreaks. Such the environment, spreading around the southern slopes of the Crimean mountains and watersheds, is especially profitable for the pests adapted to dry and warm conditions.

Gypsy moth (Lymantria dispar L.), oak leafroller moth (Tortrix viridana L.), and winter moth (Operoptera brumata L.) strongly contribute to the pathological situation in the Crimean forests [7]. Relatively warm Crimean winters, high spring-summer average daily temperatures and reduced precipitations also add to the conditions favourable for the pest outbreaks.

\subsection{OPTIMIZATiOn Of Forest Protection: Pest Monitoring AND Decision MAKing}

Evidently, pest control using only natural entomophagans is not a simple task. Its essence means switching from the attempts to exterminate the pests to the activity on their control at the densities below the level of the economic significance. In this respect, conceptual priority should displease from 
solitary actions to the long-term monitoring with acceptance of a decision on the expedient interference in natural processes. This is especially important in forests with yet not lost self-regulation.

From the theoretical point of view, pest control consists of corrections to the operating actions produced by the ecosystem genoplast. The term genoplast was introduced by M.A. Holubets [8] and means a complex of genotypes (population gene pools) of all the species interacting in the ecosystem. In any ecosystem the genoplast plays a role of operating sub-system. It has its own managing aims, which are recorded in the form of super-species associations formed during the ecosystem development. At the same time, they do not always coincide with human expectations [9, 10].

Any management requires reception and processing of the necessary information. This information may be provided by a special monitoring system, as it, for instance, have been done during the monitoring for the Lymantriids in the European and North-American forests [11]. The monitoring consists of observations on the economically important pests, including calculation of pest ovipositions, application of pheromone traps for imago, artificial refuges for larvae and pupae and calometrical method for larvae [12].

Above described experience would be very applicable and acceptable for optimal pest control in the Crimea, and its adaptation requires following steps:

- Forest pest monitoring.

- Prognosis of any step consequences on the base of current and earlier obtained data on ecosystem.

- Acceptance of only ground correcting interference in natural process.

- Estimation of the effects of the bio-preparations applied against pests.

Of course, real initiation of these approaches needs an effective information technology. We have already elaborated the preliminary database on oak leafroller moth. It is based on the data of long-term investigations on the leafroller survival at different developmental stages, adult fecundity, efficiency of larval and pupal parasites and genetic variation in the moths, their parasitoids and host plants.

Modeling of pest population dynamics requires consideration of all the accessible information. With that it should adhere to principles of chosen conception, whereas applied mathematical approach and method of the modeling should have secondary significance.

Adoption of a decision on interference in the native process is the most responsible operation in the management program, which intends choice of one or another method of pest control or rejection of any correction to the native patterns. It requires clear, scientifically based estimations of critical pest densities, which mark lower border of significant economic wastes. Negative effects of artificial interference in forest ecosystems should also be taken into account. Thus, elaboration of all the necessary criterions and the range of their importance is the first and foremost task.

Short-term and long-term effects of accepted decision may strongly differ between themselves in their consequences for the ecosystem. In this relation the fourth step (see below) should be subjected in a wider sense: it should include estimations of not only nearest efficiency of applied actions but also their long-term effects.

World-wide experience has shown that, when human takes a role of a regulator (even temporary), he as a rule disturbs ecosystem self-regulatory mechanisms [3, 13]. As a result, further management demands an additional interference and correction. Thus, the economic and ecological efficiency should be evaluated in the overall design.

Our experience of scientific researches in the Crimean forests shows that lack of co-ordination between researches and forest services in their monitoring and control programs causes both them inefficiently spending the energy and funds. Besides, in this case both them obtain the data, which could not be completely unified and jointly processed. This situation is now well understood both by scientists and forest managers, but unfortunately the database concerning the information on forest protection in Ukraine is not satisfactory. As a result, the forest-protective actions are not always adequate and scientifically based. 


\subsection{THE CONCEPT OF LIMITED INSECTICIDE APPLICATION}

The unique natural complexes of the Crimea and its South Coast require special attention to anthropogenic influences. Hence, forest protection should be based here on the limited use of insecticides and priority of biological control that also should aspire to the minimum. Any decisions in this respect should take into the consideration the long-term effects of pest control. Acceptable pest control should intend forest management methods closely approaching natural principles, which minimize risk of pest outbreaks [14].

Figure 2 shows the conceptual scheme of the pesticide-free forest protection based on natural mechanisms, which regulate pest population dynamics. In natural ecosystems this regulation is performed by the feed-backs between pest and host plant, and between pest and its consumers. Positive and negative feed-backs between trees and pests may cause cyclic processes, which for example drive population dynamics in Epirrita automnalia on birch (Betula pubescens) in Fennoscandia [15]. In this respect, periodic oscillations of pest numbers should be considered as a normal, natural process.

Abiotic factors influence the population numbers modifying its equilibrium state. Unequilibrium pest populations show strong outbreaks, when pest density significantly exceeds an ecosystem optimum, and natural regulation is inefficient. Forest service attempts to regulate this situation. The essence of these managing influences consists of effective reinforcing of feedbacks (pointers 5, 7 in fig. 2) using biological regulators. Monitoring block collects the information for further construction of predictions and decisions.

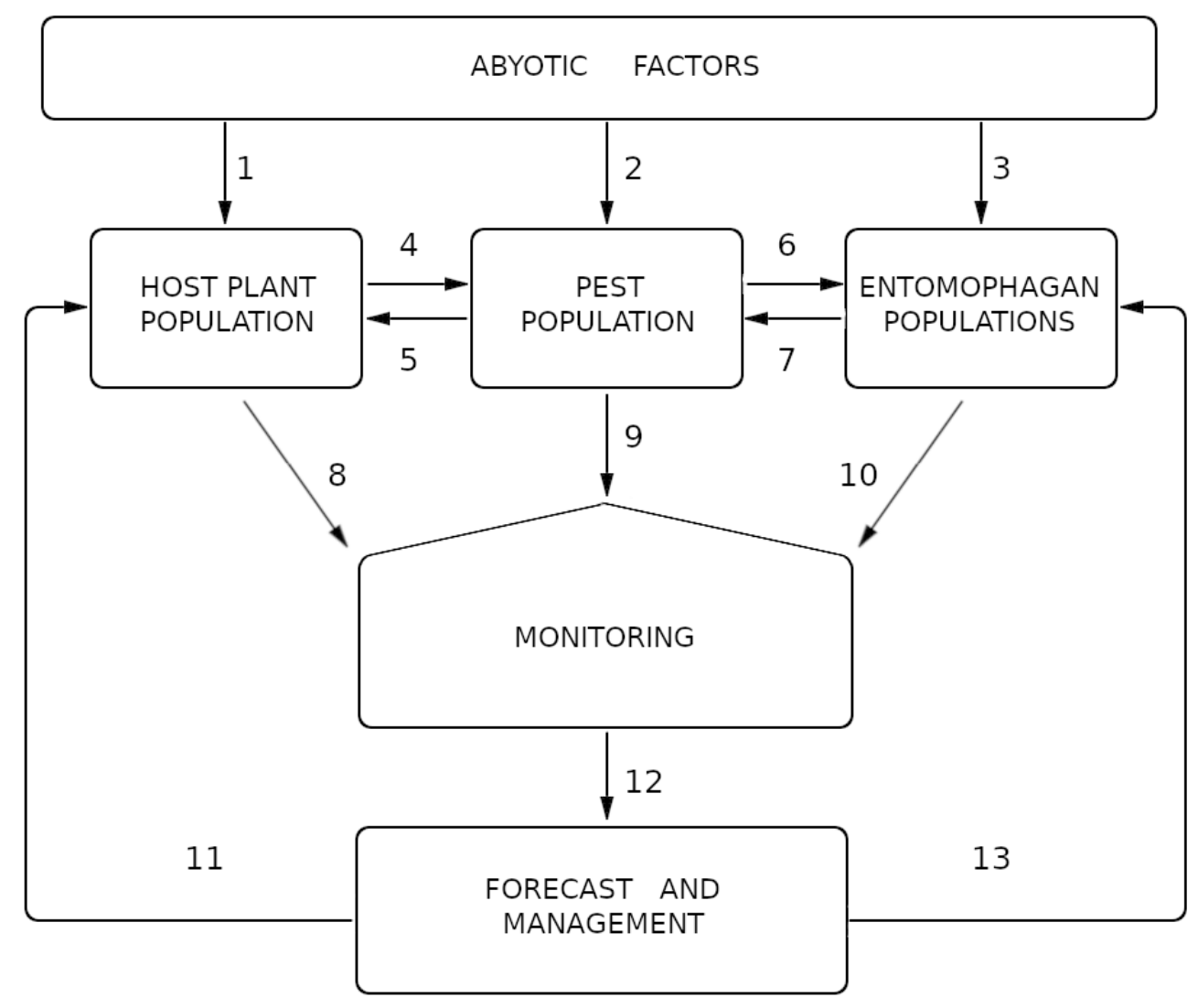

Fig. 2. Conceptual scheme of pesticide-free control of pest populations: 1 - 13 basic bonds (see text for explanation).

Pointers 1-3 in fig. 2 represents abiotic factors, mainly the weather, influencing the pest and its natural regulators. This information is also collected into the monitoring block. These data should be used appropriately because the weather could influence the situation differently in different areas [16]. Besides, it should be taken into the consideration that the temperatures vary wider in the mountains than in plain [17]. 
The most of the links, included in the process of natural regulation, belong to poikilothermic organisms that are very sensitive to the temperature factor. Temperature dynamics affects their phenological rhythms. For example, the lack of synchrony between the oak leafroller eclosion and budburst in oaks can cause a crush of the pest population [18, 19, 20, 21]. This factor is also critical for gypsy moth, while autumn humidity strongly control the winter moths in Crimea.

The pointers 4, 5 reflect interaction between pests and their host plants. Quality of an accessible food could influence oak leafroller moths [22], gypsy moths [23] and winter moths [24] densities. In this respect very interesting data were obtained for Crysomela vigintipunctata during its outbreaks in the Rain region (Germany) from 1985 to 1987 [25]. Overwintering insects were completely eliminated on some resistant trees of white willow. On the author's opinion, this was caused by high contents of tannin, rutine and some other secondary metabolites.

Eating-caused damage could also change leaf quality. For instance, oak leaves change the contents of some their basic and secondary metabolites in response to eating-caused damage by herbivores $[22,26]$. These biochemical changes decrease in the nutritional quality of secondary foliage restored after defoliation.

In the Crimean forests the gypsy and oak leafroller moths prefer to invade pubescent oaks and usually reach their higher densities there than on durmast oaks. This effect may be partially explained due to higher content of proteins-inhibitors of trypsin-like proteases in the durmast oak leaves than in pubescent oak ones [27]. At the same time, these oak species do not differ sufficiently in the contents of secondary compounds such as polyphenols [28]. Thus, patterns influencing foliage quality, i.e. quality of herbivores' forage should be considered as a major constituent in the density regulation system of forest pest populations [3, 29].

Creation of the oak populations resistant to damage by oak leafroller moths and other pests is a very perspective strategy for the long-term regulation. Resistance to the pests may be based on the variation in the phonological rhythms of host plants, as it has been shown for the oaks in the National natural park in Great Britain [30]. Biodiversity of woody plants should be incorporated as a base principle into any program on the new forest creation. Some models showed importance of this factor for prediction of oak defoliation from damage by gypsy moth larvae [4].

Diverse entomophagans influence pest populations (pointers 6,7 ) and estimation of their role is always important for bio-control. There are sufficient data on efficiency and composition of entomophagans parasitizing oak leafroller moths [31, 32, 33, 34]. In particular, we have found that a considerable part of their eggs was yearly invaded by Trichogramma telengai Sor. [35]. This species is a possible candidate for bio-control in Crimean forests. Unfortunately, species composition and regulatory effort of predator insects is not yet studied sufficiently in the Crimea.

Extensive application of bacterial preparations or formulations showed good results for suppressing the pest outbreaks in the Crimean forests. Evidently, these preparations will remain irreplaceable in this application. Such viral preparations as Virin-NSH (based on the nuclear polyhedrosis virus) were applied effectively against gypsy moth in Crimea. Study of population susceptibility of T. viridana and $L$. dispar to diverse bacterial and viral infections can raise effectiveness of their application. Our results have shown high informative outcomes from evaluation of genetic changes in the T. viridana Est-3 locus in response to application of sub-lethal doses of such bacterial preparation as "lepidocide". Protease locus Pts-4 could also be included in genetic monitoring of the pest populations [36]. Unfortunately, genetic methods of pest control, such as introduction of sterile males, are not usual in forestry management programs in Crimea. These methods could contribute to the system of pesticide-free control, as it has been shown for L. dispar at its latent-phase in the NorthAmerican forests [37].

Forest protection actions could influence natural entomophagans exploiting populations of target pest (pointer 7). Although there are sufficient data on this theme, both the factors, microbiological agent and decreasing host density, influencing the entomophagan population should be taken into the consideration. 
Analytic block providing collection and processing of all the accessible information (pointers 8-10) occupies central place of the pest management system. The data on the abiotic factors, biotic factors including the ecological indexes of pest populations: density, surviving, fecundity, biotic potential, emigration, immigration form the source for decision-making activity.

Recently obtained data show that genetic factors may play a role in the pest population dynamics [36]. The application of allozyme-analysis method allowed displaying genetic alterations on the diverse stages of the T. viridana ontogenesis in esterase, protease and some other loci $[38,39]$. Larval coloring phenes may also serve as good markers for the genetic monitoring in the pest populations [40]. These approaches were elaborated for T. viridana and they allow predicting the population states, and also forecasting the changes of insect density caused by the application of control methods. Combination of such methods as pheromone catching of males and their genotype screening may give the sufficiently reliable prognosis of the pest population state.

Manager block provides the adoption of optimum decisions on the base of information, obtained from the monitoring (pointer 12). The manager influences (pointers 11 and 13) affect the target pest. Acceptable scientific prognosis and management should be based on ecological-genetic analysis of interactions between populations in the chain: populations of arboreal plants - pest populations populations of entomophagans [41]. Herewith, it is necessary to consider that neither natural nor introduced entomopagan species could not provide full and long-term regulation. We argue for a complex of approaches and means where any entomophagan should have its definite place.

Abrupt changes in numbers, typical for gypsy moth and in less degree for oak leafroller and winter moths is probably a consequence of their relatively short evolutionary ages. The mechanisms of homeostasis, working on intrapopulation and ecosystem levels, do not reach the degree when adaptation to environmental conditions approaches the most economical method. Besides frequent pest outbreaks may be provoked by unreasoned control actions or other human influences.

\subsection{Systems of PREVENTIVE AND APPLIED PeSt BIO-CONTROL IN THE CRIMEAN Forests}

The long-term pest control in the Crimean forests should be based on the concept of limited use of pesticides. These current tasks should be taken into elaboration on local levels and should be subjected to strategy of development and preservation of forest ecosystems [6]. The complete spectrum of these tasks represents the system of preventive and current bio-control. Preventive bio-control is a complex of forestry and biotechnical practices undertaken with an aim to form unfavourable conditions for pests. Current bio-control includes active application of bio-control actions for the suppression of pest outbreaks.

Crimean forests are heterogeneous in respect to their resistance to different pests. Therefore, it is possible to distinguish areas of primary, secondary and tertiary niduses of pest outbreaks. Estimation of damage caused by gypsy moth in USA showed that forest-protection treatments are economically reasonable only in the plantations, which are the most susceptible to the herbivore [42]. Therefore search and exposure of primary niduses is a very actual task.

The primary pest niduses arise under the conditions that are most favourable for the pest, mainly in mono-cultured, thinned, cleared forests with low quality stand that loses its biological resistance to the pest. This is peculiar for the Crimean forests, which are mainly represented by forest areas on seaside that are exposed to strong recreational pressure. The pest densities increase here faster and more dramatically than in other areas, and are frequently accompanied with full defoliation. Hence, the natural regulation is almost lost here.

Secondary niduses may be observed under the conditions that are less favourable for pest outbreaks. The pest numbers grow slowly with relatively rare cases of full defoliation. This is a category of forests with partial loss of natural regulation. In Crimea they are represented by a majority of mountain forests, which are exposed to a moderate recreation pressure.

The tertiary niduses arise in forests that belong to a category of biologically resistant plantings. These forests have high levels of biodiversity and stratification, high quality stands and a complicated 
overall ecological structure. Niduses of pest outbreaks rarely happen here, and may arise only due to migration from pandemic areas. An example was observed in 1988-1989 years, when gypsy moth outbreak spread over the zones of steppe and forest-steppe in European Russia and Ukraine. However, the forests remained less damaged due to the biological steady state.

Therefore, preventive and current bio-control should differ among these different categories of forests in respect to the necessary amount of forestry, biotechnical and protective actions. Description of diverse bio-control actions in these different categories of forest is represented in Tab. 1.

\begin{tabular}{|l|l|l|l|}
\hline Nidus & Potential outbreak & Forecast structure & Control measures \\
\hline Primary & Mass forest \\
\hline Secondary & $\begin{array}{l}\text { Slow growth of the pest } \\
\text { population numbers }\end{array}$ & Complex & $\begin{array}{l}\text { Reconstruction of } \\
\text { plantations } \\
\text { control }\end{array}$ \\
\hline Tertiary & $\begin{array}{l}\text { Little chance of any pest } \\
\text { outbreak }\end{array}$ & Very complex & Operative bio-control \\
\hline
\end{tabular}

Tab. 1. The characteristics of bio-control in primary, secondary and tertiary pest outbreak niduses.

The system of bio-control actions is simplest in the forests which belong to the category of tertiary pest niduses. No specific forestry and biotechnical actions are necessary there. They may serve as standards of sustainable forest ecosystems. Natural complex of entomorphagans and pathogens, mechanisms of self-regulation and ecosystem ties should be studied there. When even the pest density threshold is exceeded, protective actions may be restricted to current bio-control with application of microbiological preparations. If defoliation is less than $30 \%$, then any interference would be economically and ecologically inexpedient. Air-treatment using only bio-formulations (preparations) should be applied when defoliation is from 30 up to $80 \%$. Only when defoliation exceeds $80 \%$, treatment by bio-formulations (preparations) mixed with immunodepressants (dimilin) would be necessary.

Aesthetic requirements to determination of permissible defoliation level are sufficient for the recreational areas. Acceptance of $25 \%$-level of defoliation as an aesthetic requirement allowed more than two-fold decrease in pesticide applications against orangestriped oakworm (Lepidoptera: Saturniidae) in streets and parks of Norfolk, Virginia (USA) [43].

More complex system of the pest bio-control is required in the forests with wicked natural resistance. In the secondary niduses of T.viridana, for example, preventive bio-control should include attraction of insectivorous birds and re-establishing of the forest red ants. The observations and studies of retaining predators and their regulating role showed their effectiveness against $L$. dispar at the pest's low density level. The role of ants was peculiarly significant nearby ant-hills [44].

Attraction of parasitic and predatory insects may serve as strong protective action. Detailed study of an egg-eating Trichogramma minutum in Canada showed prospectively of its application against the leafroller Choristoneura fumiferana [45]. Intromission of a specialized egg-eater Tr. telengai into niduses of oak leafroller moth in the Crimean forests may also bring good results.

The method of seasonal colonization of viruses as preventive protection measure against gypsy moth [46] also is a good tactics. The current bio-control in the Crimean forests presumes: single application of bacterial preparations against larvae of pests of early-spring phenological group; single application of bacterial preparations against T. viridana and other pests of early-spring group if defoliation has exceeded $30 \%$.

Use of polymeric compositions, which overwhelm the larval eclosion from eggs, is the perspective method for current regulation of gypsy moth density [47]. As an experience show, suppression of the 
winter moth outbreaks in Canada could be reached using introduction of parasitoids. They effectively decreased pest numbers and local unspecialized predators completed the suppression [48].

The preventive bio-control is difficult in the forest areas with completely lost natural resistance because they need deep interference for restoration of their ecological state. Current bio-control actions are usually inefficient there due to lack of long term effects. Nevertheless, use of chemicals is in conflict with requirements of recreation zone even when defoliation reaches $100 \%$ level.

The application of bacterial preparations on the base of Bacillus thuringiensis is already well studied and is recommended for practice [49]. Virulent strains of B. thuringiensis were successfully applied against gypsy moth in three Canada provinces [50].

There are some positive results of $B$. thuringiensis application against new $T$. viridana larvae in the Crimean forests using local air-treatments. At the same time, application of the bacteria against $L$. dispar was not effective there. The pest outbreak still resulted in strong defoliation decreasing aesthetic quality of recreational zone, but chemical pollution of the area was avoided.

The causes of post-outbreak depression are not well understood yet as well as the role of parasites in this process. At the same time, it is well known that the tachina flies were an important natural factor decreasing the numbers of gypsy moth over 1984-1986 in Germany [51]. The infection of the pest by the tachina flies (Parasitiqena silvestris) reached $100 \%$ to the end of the outbreak [52]. The gypsy moth outbreak was repeated in a decade. At this time eggs of gypsy moth were infected by Ooencyrtus kuvanae and larvae were parasitized by tachina flies. The parasite action was completed by effects of damp weather and initiated polyhedrosis virus infection [53]. At the same time, long-term experience of gypsy moth control in France showed that the control actions over the large forest areas, as a rule, resulted only in some delay of an outbreak [54].

More acceptable forest protection strategy in the zones of intensive recreation lies in the restoration of forests. It includes: increase of biodiversity, planting of soil-improving shrubberies, creation of glades with nectariferous plants for attraction of useful insects-regulators. In some areas of the Crimean forests the deciduous species were replaced by coniferous species. However, extended plantings of coniferous species undergo strong frequent fires, damage from which considerably exceeds the damage from pest-caused defoliation. In this reason, The narrow planting ribbons of coniferous that cross mountain slopes decrease in probability of fires, and, at the same time, they promotes effectiveness of entomophagans [55]. Besides, forestry specialists are not focussing on the creation of resistant forests by introducing of deciduous species.

Comparative data on three oak species in south New England (USA) have shown that the most light-loving and drought-resistant specie, Q. velutina, is the most variable [56] and therefore could be acceptable for these purposes. Correct selection of plants could be probably the most effective way for creating balanced resistant forests. For instance, in north Florida Q. germinata oaks were lowly damaged by Stilbosis quadricustatella moths, and main part of their eggs died till larval eclosion. These oaks had smaller leaves and earlier vegetation than other oaks. On the whole, mortality of the moths was stronger affected by host plants than by their natural enemies [57].

All pest-control measures should be elaborated as a successive chain of steps joining in a common ecologically and economically sound system. Preventive and current bio-control actions become easy and soft with increase in the forest's ecosystem complexity and restoration of natural self-regulation. 


\section{REFERENCES}

[1] Watt K.E.F. Ecology and Resource Management a Quantitative Approach. New York and San Francisco, 1968.

[2] Apostolov L.G., Ivashov A.V. Mathematical Methods in Ecology. Kiev, 1980. (in Russian)

[3] Thompson W.A., Holling C.S., Kira I.N., Huang C.C., Vertinsky I. Evaluation of alternative forest system management policies. Journal of Environmental Economy and Management, 6 (1979), 51-68.

[4] Gottschalk K.W., Colbert J.J., Feicht D.L. The mortality risk of oak due to gypsy moth. European Journal of Forest Pathologym, 28 (2) (1998), 121-132.

[5] Siepel H. Decision-support systems for nature management. Biodiversity Letters, 3 (4-5) (1996), 157-161.

[6] Berlyn G.P., Ashton P.M.S. Sustainability of forests. Journal of Sustainable Forestry, 3 (2-3) (1996), 77-89.

[7] Apostolov L.G., Ivashov A.V., Kolodochka A.A. Retrospective analysis and optimization of protective measures in forest and park plantings of the Crimean South coast. Scientific Notes of Simferopol University, 46 (7) (1998), 11-19. (in Russian)

[8] Holubets M.A. Actual Problems of Ecology. Kiev, 1982. (in Russian)

[9] Ivashov A.V. Biogeocenotical systems and their attributes. Journal of General Biology, 52 (1) (1991), 115128. (in Russian)

[10] Holubets M.A. From Biosphere to Sociosphere. Lviv, 1997. (in Ukrainian)

[11] Schönherr J. Outbreak characteristics of Lymantriids. In: Proceedings of the Conference on Lymantriidae: Comparative Features New and Old World Tussock Moths. New Haven, Connecticut, June 26-July 1, 1988. Broomal Pennsylvania, 1990, 171-181.

[12] Mason R.R. Monitoring population chance in the Lymantriidae. In: Proceedings of the Conference on Lymantriidae: Comparative Features New and Old World Tussock Moths, New Haven, Conn., June 26 - July 1, 1988. Broomal Pennsylvania, 1990, 183-201.

[13] Marshakov V.G. Control of pest numbers in system: host is parasite (Insecta) on the base of forecast of result of species interaction. PhD dissertation, Leningrad, 1985. (in Russian)

[14] Führer E. Faktoren der Latenzstabilisierung bei Waldinsekten-populationen im Dienste des praventiven Waldschutzes: [Vortr.] Entomologentag., Gottingen, 27 March-1. April 1995. Mitteldeutsche Gessellschaft allgemeine und angewandte Entomologie, 10 (1-6) (1995), 13-19. (in German)

[15] Haukioja E. Cyclic fluctuations in density: interactions between defoliator and its host tree. Acta oecologica, 12 (1991), 77-78.

[16] Watt K.E.F. The use of mathematics and computers to determine optimal strategy and tactics for and given insect pest control problem. Canadian Entomologist, 96 (1964), 202-220.

[17] Watt K.E.F. Dynamic programming, Look programming, and the strategy of insect pest control. Canadian Entomologist, 95 (1963), 525-536.

[18] Rubtsov V.V., Rubtsova N.N. Analysis of interaction of herbivorous insects with oak-tree. Moscow, 1984. (in Russian)

[19] Sirenko M.D. Physiology-ecological aspects of ineractions of green oak leafroller moth (Tortrix viridana L.) with populations of species of Quercus genera in mountain forests of Crimea. Ecosystems of the Crimea, their optimization and protection, Kiev, 1989, 35-54. (in Russian)

[20] Schütte F. Untersuchungen uber die Populations dynamik des Eichenwicklers (Tortrix viridana L.). Teil I. Zeitschrift fur angewandte Entomologie, 40 (1) (1957a), 1-34.

[21] Schütte F. Untersuchungen uber die Populations dynamik des Eichenwicklers (Tortrix viridana L.). Teil II. Zeitschrift für angewandte Entomologie, 40 (3) (1957b), 285-331.

[22] Ivashov A.V. Physiology-biochemical basis of interaction of oak and green oak leafroller moth in forest biogeocenoses of Prisamarye. PhD Dissertation, Dnepropetrovsk, 1977. (in Russian)

[23] Taranukha M.D. The role of chemical content of forage plants in connection with development and fecundity of gypsy moth (in Russian). In: Scientific works of the Institute of Entomology and Phytopathology of Academy of Sciencies of UkSSR, 3 (1952), 41-53.

[24] Feeny P.P. Seasonal changes in oak leaf tannins and nutrients as and cause of spring feeding by winter moth caterpillars. Ecology, 51 (4) (1970), 565-581.

[25] Topp W. Massenvermehrungen von Insekten, Verteidigungsreaktionene von Pflanzen. Eine fallstrudie am Beispiel des Weidenblattkafers Crysomela vigintipunctata. Westdeutgche Entomologentag, 1996, 1-18. 
[26] Feeny P.P. Inhibitory effect of oak leaf tannins on the hydrolysis of proteins by trypsin. Phytochemistry, 8 (1969), 2119-2126.

[27] Medvedkov A.A., Ivashov A.V. Seasonal dynamics of content of inhibitors of trypsin-like proteases in leaves of durmast oak (Quercus petraea Liebl.). Ukrainian Biochemical Journal, 68 (6) (1996), 44-50. (in Russian)

[28] Boyko G.E., Ivashov A.V. Some features of structure of secondary metabolites in leaves of Quercus pubescens Willd., Q. petraea Liebl. and Q. robur L. In: Ecosystems of the Crimea, their optimization and protection. Kiev, 1997, 55-60. (in Russian)

[29] Führer E. Basic problems of long-term regulation of insect pest populations in and managed forest. Zeitschrift fur angewandte Entomologie, 99 (1985), 67-73.

[30] Satchell J.E. Resistance in oak (Quercus spp.) to defoliation by Tortrix viridana L. in Roudsea Wood National Nature Reserve. Annals of Applied Biology, 50 (3), 1962, 431-442.

[31] Podmarkov N.Ju. Biology and ecology of insects is parasitoids of green oak leafroller moth (Tortrix viridana L.) in the Mountain Crimea. PhD Dissertation, Voronezh, 1986. (in Russian)

[32] Ivashov A.V., Podmarkovand N.Ju., Sirenko M.D. Larvae parasitoids of green oak leafroller moth in Crimea. Lesnoy journal, 3 (1986), 108-110. (in Russian)

[33] Ivashov A.V., Suslova G.N. Trichogramma embriophagum Htg.-egg parasite of green oak leafroller moth. In: Theses of III Congress of Ukrainian Entomological Society, Kiev, 1987, 78-79. (in Russian)

[34] Zerova M.D., Kotenko A.G., Seregina L.J., Tolkanits V.I. Entomophagans of green oak leafroller moth and gypsy moth of Southwest of the European part of the USSR. Kiev, 1989. (in Russian)

[35] Ivashov A.V., Suslova G.N. The wintering storage of Trichogramma telengai Sor. - egg parasite of green oak leafroller moth Tortrix viridana L. in Crimean oak forests. Lesnoy Journal, 2 (1990), 23-28. (in Russian)

[36] Simchuk A.P., Ivashov A.V., Companiytsev V.A. Genetic patterns as possible factors causing population cycles in oak leafroller moth, Tortrix viridana L. Forest Ecology and Management, 113 (1999), 35-49.

[37] Mastro V.C., O'Dell T.M., Schwalbe C.P. Genetic control of Lymantriidae: prospects for gypsy moth management Lymantriids. In: Proceedings of the Conference on Lymantriidae: Comp. Features New and Old World Tussock Moths. New Haven, Connecticut, June 26-July 1, 1988. Broomal Pennsylvania, 1990, 275-302.

[38] Simchuk A.P., Ivashov A.V. The properties of the complex of unspecific esterases of green oak leafroller moth. Ukrainian Biochemical Journal, 62 (4) (1990), 44-49. (in Russian)

[39] Simchuk A.P. Genetic processes in natural populations of green oak leafroller moth. Thesis of $\mathrm{PhD}$ Dissertation, Moscow, 1994. (in Russian)

[40] Kireeva A.M. Intrapopulational aspects of numbers dynamics of gypsy moth. In: Materials of the 8th Congress of the All-Union Entomological Society. Vilnius, 1985, 83-84. (in Russian)

[41] Simchuk A.P. The role of intraspecific heterogeneity in consortive ties of herbivorous insects from oak plantings in the Crimea: theoretic and applied aspects. DSc Dissertation, Dnepropetrovsk, 2009.

[42] Gottschalk K.W. Impacts, silviculture and the gypsy moth. In: Proceedings of the Conference on Lymantriidae: Comparative Features New and Old World Tussock Moths New Haven, Connecticut, June 26-July 1, 1988. Broomall, Pennsylvania, 1990, 217-232.

[43] Coffelt M.A., Schultz P.B. Development of an aesthetic injury level to decrease pesticide use against orangestriped oakworm (Lepidoptera: saturniidae) in an urban pest management project. Journal of Economical Entomology, 83 (5) (1990), 2044-2049.

[44] Weseloh R.M. Predation of lymantriids by arthropods Lymantriids. In: Proceedings of the Conference on Lymantriidae: Comp. Features New and Old World Tussock Moths. New Haven, Connecticut, June 26-July 1, 1988. Broomal Pennsylvania, 1990, 489-499.

[45] Sandy M. Smith. Inundative release of the egg parasitoid, Trichogramma minutum (Hymenoptera: Trichogrammatidae), against forest insect pests such as spruce budworm, Choristoneura fumiferana (Lepidoptera: Tortricidae): the Ontario project, 1982-1986. Memoires of Entomological Society of Canada, 153 (1990), 1-87.

[46] Orlovskaya E.V. The purposes, problems and prospects of application of entomopathogenes viruses against harmful insects. Problems of Entomology in Russia, 2 (1998), 66. 
[47] Sangalov Ju.A., Musin M.A., Antonova N.E. Insecticide-free technology protection of wood with use of modern means. In: Forests of Bashkortostan: and Modern Status and Prospects: Materials of ScientificPractical Conference. Ufa, 1997, 193. (in Russian)

[48] Roland J., Embree D.G. Biological control of the winter moth. Annual Review of Entomology, 40 (1995), 475-492.

[49] Harper J.D. Forest Insect Control with Bacillus thuringiensis: Survey of Current Knowledge. Auburn Univ. Auburn., 1974.

[50] Bernier R.L. Jr., Gannon D.J., Moser G.P., Mazzarello M., Griffiths M.M., Guest P.J. Development of and novel Bf strain for the control of forestry pests. In: Proceedings of the International Conference on Crop Protection, Pests and Deseases. Brighton, November 19-22, 1990, Vol. 1. Farnham, 1990, 245-252.

[51] Bogenschutz H., Maier K., Trzebitzy C. Gypsy moth outbreak and control in southwest Germany, 19841986. In: Proceedings of the Conference on Lymantriidae: Comparative Features New and Old World Tussock Moth. New Haven, Connecticut, June 26-July 1, 1988. Broomal, Pennsylvania, 1990, 89-100.

[52] Maier K., Bogenschutz H. Massenwechsel von Lymantria dispar L. (Lep., Lymantriidae) und die Regulation durch Parasitoide wachrend einer Gradation in Sudwestdeutschland 1984-86. Zeitschrift fur Pflanzenkrankh. und Pflanzenschutz, 97 (1990), 381-393.

[53] Bathon H. Zur Bedeutung der Parasitoide beim Zusammenbruch der Schwammspinner-Gradation in Südhessen. In: Vortr. Symp. "Massenvermehr. Forstschmetterling: Erkenntnisse, Efahren und Bewert. Jüng Kalamitütsereign.", Braunschweig, 7.-8. Nov.1995 . Mittel Biologie Bundesamst. Land- und Forstwirtschafft Berlin-Dahlem. Braunschweig, 1996, 117-132.

[54] Chagot D. Le Bombyx disparate Lymantria dispar L., quelques remarques sur un ravageur forestier. Bulletin Societe des amis de Musique Chartres et nature, 17 (1997), 41-43.

[55] Sharov A.A. Influence of spacial structure of interacting populations of European pine sawfly (Neodiprion sertifer) and its parasite (Exenterus abruptorius) on their numbers dynamics.. Zoologicheskiy zhurnal, 58 (3) (1979), 356-365. (in Russsian)

[56] Ashton P.M.S., Berlyn P. A comparison of leaf physiology and anatomy of Quercus (section Erythrobalanus-Fagaceae) species in different light environments. American Journal of Botany, 81 (5) (1994), 587-597.

[57] Mopper S., Simberloff D. Differential herbivory in an oak population: The role of plant phenology and insect performance. Ecology, 76 (4) (1995), 1233-1241.

Address: Anatoliy Ivashov, V.I. Vernadski Taurida National University, 4 Vernadskogo Blv., Simferopol 95008, Ukraine;

Andriy Simchuk, Vasyl Stefanyk Precarpathian National University, 57 Shevchenko St., IvanoFrankivsk 76018, Ukraine.

E-mail: avi@crimea.edu; andriy.simchuk@pnu.edu.ua.

Received: 10.11.2020; revised: 25.12.2020.

Івашов Анатолій, Сімчук Андрій. Концепція безпестицидного контролю шкідників у лісах Криму. Журнал Прикарпатського університету імені Василя Стефаника, 7 (4) (2020), 34-45.

Дубова зелена листовійка (Tortrix viridana L.), непарний шовкопряд (Lymantria dispar L.) та зимовий п'ядун (Operoptera brumata L.) суттево впдивають на патологічній стан кримських лісів, які у свою чергу зазнають сильного рекреаційного тиску, що сприяе ослабленню лісових екосистем. У зв'язку із цим, розробка концепції охорони лісів без пестицидів, яка передбачає оптимальний баланс між природними можливостями саморегулювання та управління, враховуючи довгострокові 
наслідки, є дуже актуальною. У порівнянні із традиційним підходом більш прийнятна стратегія охорони лісу в зонах інтенсивного відпочинку полягає у відновленні лісів. Вона вкдючає: збільшення біорізноманіття, насаджень чагарників, що поліпшують грунт, створення галявин з нектароносними рослинами для залучення корисних комах-регуляторів. У деяких районах кримських лісів листяні породи замінили хвойними. Однак тривалі посадки хвойних порід зазнають сильних частих пожеж, пошкодження яких значно перевищує збитки, спричинені дефоліацією шкідників. 3 цієї причини вузькі посадкові стрічки хвойних порід, що перетинають гірські схили, зменшують ймовірність пожеж, i, в той же час, вони сприяють ефективності ентомофагів. Крім того, спеціалісти лісового господарства не зосереджуються на створенні стійких лісів шляхом інтродукції дистяних порід. Практичні кроки запропонованої концепції включають профілактичну та сучасну біологічну боротьбу зі шкідниками та розрізняються у первинних, вторинних та третинних осередках спалахів шкідників у кримських дісах. Усі заходи боротьби з шкідниками мають розроблятися як послідовний ланцюжок етапів, що об'єднуються в загальну екологічно та економічно обгрунтовану систему. Профілактичні та поточні дії з біоконтролю мають ставати більш легкими та м'якими із збільшенням складності екосистеми дісу та відновленням природної саморегуляції.

Кдючові слова: шкідники, дісогосподарський менеджемент, біоконтроль. 